\title{
RAMARIA FAGICOLA (FUNGI, BASIDIOMYCOTA) - THE FIRST RECORD FOR POLAND, AND FROM A NEW SUBSTRATUM
}

\author{
JANUSZ ŁUSZCZYŃSKI \\ Department of Botany, Institute of Biology, Jan Kochanowski University \\ Świętokrzyska 15, 25-406 Kielce, Poland \\ e-mail: jluszcz@pu.kielce.pl
}

(Received: February 16, 2009. Accepted: September 29, 2009)

\begin{abstract}
Ramaria fagicola is a rare European species. It was previously known only from three localities in western Europe. The species is reported here from Poland, where it was first observed on decomposing wood of Pinus sylvestris in the Wierzchlas reserve in Bory Tucholskie Forest (N Poland). It is the first record of the fungus on conifer wood as habitats associated with deciduous wood, mostly Fagus, reported in literature.
\end{abstract}

KEY WORDS: Lentoramaria, Bory Tucholskie Forest, N Poland.

\section{INTRODUCTION}

The genus Ramaria Fr. ex Bonord. is divided into 4 subgenera: Ramaria, Laeticolora Marr \& Struntz, Echinoramaria Corner and Lentoramaria Corner, due to differences in the spores morphology, and the structure of vegetative fruit bodies hyphae. Ramaria fagicola belongs to the subgenus Lentoramaria.

Spores in species of the subgenus Lentoramaria are verrucose, almost smooth or smooth, which distinguishes them from other subgenera. Fruitbodies growing on wood or humus. Stem flesh usually inamyloid. Well developed dimitic rhizomorphs. Representatives of the subgenera Echinoramaria and Lentoramaria are saprobes while species of the subgenera Ramaria and Laeticolora are thought to be ectomicorrhizal (Petersen 1997).

The genus Ramaria comprises ca. 300 species worldwide, ca. 100 species in Europe and 28 species in Poland (Wojewoda 2003; Łuszczyński 2008; Karasiński 2009). The number of species in Poland has increased in recent years in response to the growing interest in the genus and further records of Ramaria are likely to be reported from Poland in the future.

The aim of the study is to describe Ramaria fagicola as a species new to the mycobiota in Poland. It is interesting that the knowledge on the species is enriched by new ecological data on the development of the mycelium on conifer wood as the fungus was previously observed exclusively on deciduous wood.

\section{MATERIAL AND METHODS}

Fruitbodies of Ramaria fagicola collected in the Wierzchlas reserve in the Bory Tucholskie Forest were examined. Fresh sporocarps were treated in $10 \% \mathrm{KOH}$ to determine characteristic colour reactions of rhizomorphs, the stem and the hymenium. Drawings of spores, basidia and hyphae were made from photographs of images taken with a light microscope. Taxonomically important organoleptic characteristics such as the smell and taste were observed from fruitbodies when fresh.

The specimens deposited in the Herbarium of Department of Botany (KTC 3877), Institute of Biology of the Świętokrzyska Academy in Kielce and in the Herbarium of the Tennessee University.

\section{DESCRIPTION OF THE SPECIES}

\section{Taxonomy}

Ramaria fagicola R.H. Petersen, Bibliotheca Mycologica 43: 112 (1975) - Gomphaceae Donk, Gomphales Jülich, Phallomycetidae K. Hosaka, Kastellano \& Spatafora, Agaricomycotina Doweld, Agaricomycetes Doweld, Basidiomycota R.T. Moore, Fungi (Kirk et al., 2008).

\section{Macroscopic and microscopic description}

Fruitbodies up to 6-7 $\mathrm{cm}$ high, slender, caespitose, arising as several elongated stipes, repeatedly branched. Rhizomorphic strings white, up to $1 \mathrm{~mm}$ thick, when fresh and treated with $10 \% \mathrm{KOH}$ become lemon yellow. Stipe slen- 

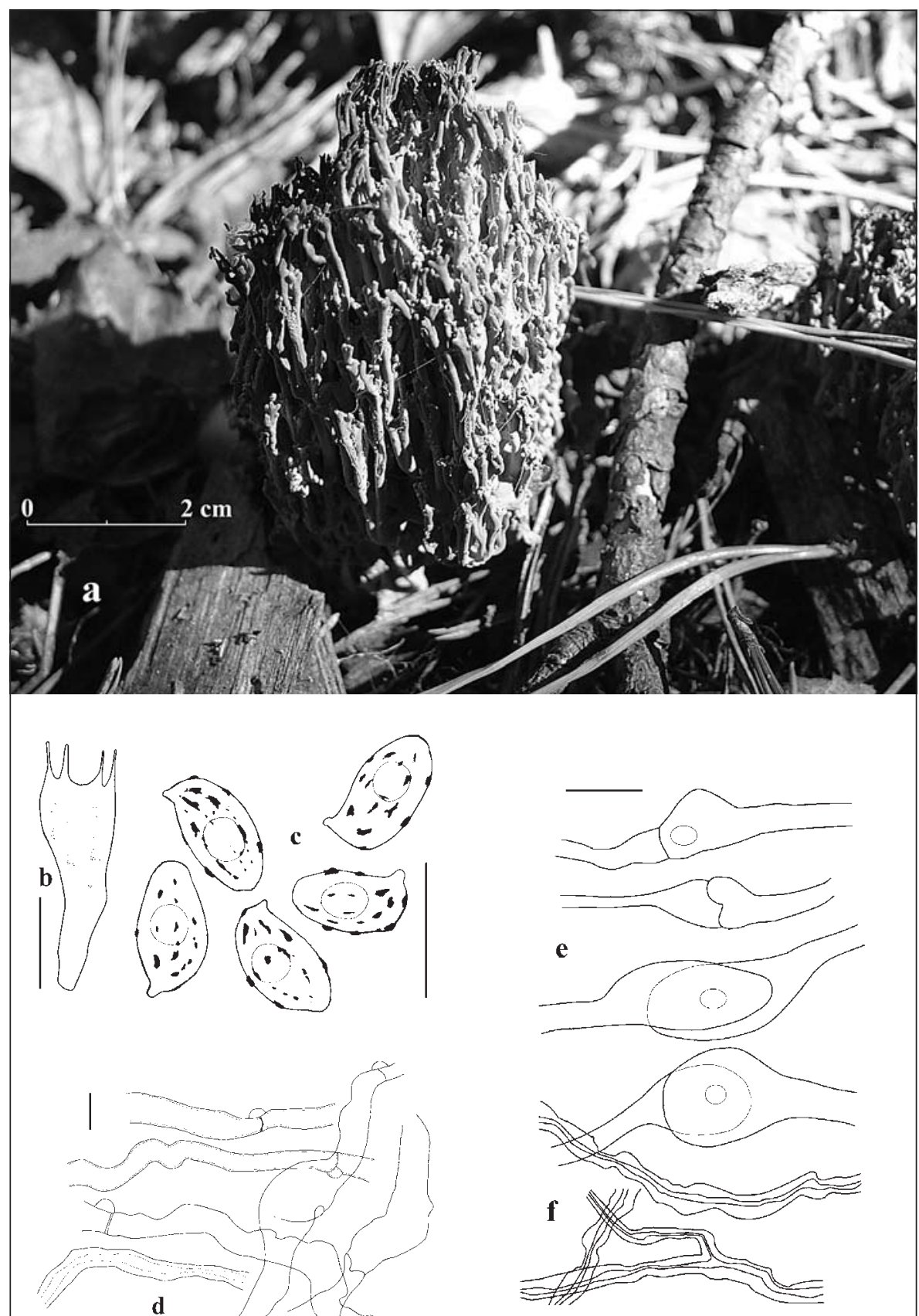

Fig. 1. Ramaria fagicola: $\mathrm{a}$ - fruit-body; $\mathrm{b}$ - basidium; $\mathrm{c}$ - spores; $\mathrm{d}$ - hyphae of trama in branches; $\mathrm{e}$ - clamps connection; $\mathrm{f}$ - skeletal hyphae in rhizomorphs; scale bars $=10 \mu \mathrm{m}$

der, up to $1 \mathrm{~cm}$ long, up to $3 \mathrm{~mm}$ thick, watery yellowish below, and reddish brown above. Branches slender, erect, reddish brown, rebranching irregularly, somewhat flattened, especially near axils. Axils rounded to lunate, sterile, and decurrent in a channel or line. Apices of branches very delicate, slender, erect, finely digitate, weakly yellowish when fresh, and when dried somewhat darker than branches. Hymenium unilateral, when rubbed and/or damaged changing to brown-(vinous) rosa-lilac colour. Fresh flesh white on cross-section, not changing colour when exposed to air. Taste mild and sweetish (never bitter!) but odour resembling rotting wood or cellar-like (not anise!).

Spores of Ramaria fagicola measuring 8.1-10.0×5.0-5.4 $\mu \mathrm{m}$, cylindric to narrowly ellipsoid, and obscure rough with not prominent apiculus. Basidium with (2)-4 sterigmata, ca. $43 \times 5.4 \mu \mathrm{m}$. Hyphae of branches trama monomitic, ge- nerative, 3.8-13(17) $\mu \mathrm{m}$ diameter, diverse, from thin- to thick-walled, and also pseudoskeletal with wall up to 2.5 $\mu \mathrm{m}$. Hyphae in rhizomorphs dimitic, generative and skeletal. Thin-walled generative hyphae, up to $8 \mu \mathrm{m}$ with ampullate, inflated clumps up to $16 \mu \mathrm{m}$ broad (Fig. 1). Skeletal hyphae 2.5-4.0 $\mu \mathrm{m}$ diameter, tapering gradually at the end, without septa, rigid, straight, and gnarled. Observed under the microscope in a fresh specimen of subhymenium layer, long cells filled with oil drops, and with gloeocystidia appearance.

\section{Distribution in Poland}

Described site is situated in Northern Poland, West Pomeranian, in the Bory Tucholskie Forest, $40 \mathrm{~km} \mathrm{~N}$ of Bydgoszcz city, and ca. $17,5 \mathrm{~km} \mathrm{SE}$ of Tuchola town, in the Wierzchlas reserve $\left(53^{\circ} 32^{\prime} \mathrm{N}, 18^{\circ} 07^{\prime} \mathrm{E}\right)$. The fruit bodies 
TABLE 1. Comparison of selected features of the Ramaria fagicola and R. stricta (acc. to Petersen 1975).

\begin{tabular}{lll}
\hline Features & \multicolumn{1}{c}{$R$. fagicola } & \multicolumn{1}{c}{ stricta } \\
\hline Spores & $8.1-10.0 \times 5.0-5.4 \mu \mathrm{m}$ & dimitic \\
System of hyphae & dimitic & yellow, yellow-ochre \\
Colour of apices & weakly yellowish & brown-vinous-red \\
Colour of flesh in cross-section & whitish & cupper, orange, brownish \\
Colour of flesh in $10 \% \mathrm{KOH}$ & brownish & mildly spicy to bitter \\
Taste & mild and sweetish & anise \\
Odour & rotting wood or cellar-like (not anise!) &
\end{tabular}

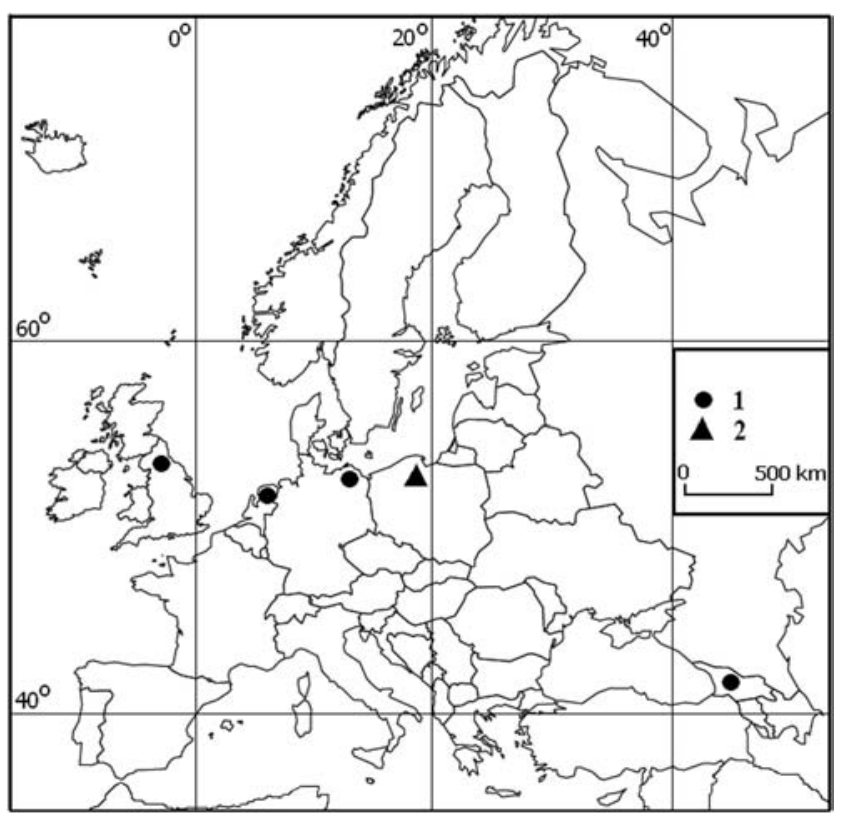

Fig. 2. Distribution of Ramaria fagicola in Europe: 1 - known localities; 2 - new locality.

grow in groups on the rotting wood of coniferous stump (Pinus sylvestris) in oak-linden-hornbean forest Tilio-Carpinetum with Pinus sylvestris.

\section{World distribution}

Ramaria fagicola is the species occurring in the Northern hemisphere. This species is very rare and until now was known only from a few places, mainly from Europe, England, Netherlands (Petersen 1975; Jülich 1984), Germany (http://www.uni-greifswald.de/ mycology/kartierung_mv/GesamtlisteMV_qberGesamt11Seite24.html), and also from Asia, Georgia (former USSR, - R.H. Petersen, pers. comm.) (Fig. 2).

\section{DISCUSSION}

Ramaria fagicola is very similar in shape and colour especially to $R$. stricta. Comparison of selected features of the Ramaria fagicola and $R$. stricta is given (Table 1). $R$. stricta grows on rotting decidous and coniferous woods, while $R$. fagicola was until now described only from decidous wood (Fagus). This record is the first case of finding $R$. fagicola specimens in Poland, and collected from a new substratum, conifer wood (Pinus). Determination of Ramaria stricta during the field collection demands a special care due to the possibility of misidentification. It is characteristic for Ramaria fagicola to be distributed mostly in areas under the influence of oceanic or marine climate.

\section{ACKNOWLEDGMENTS}

I would like to express my great thanks to Professor Ronald H. Petersen from the University of Tennesee (USA) for determination of specimens of Ramaria fagicola.

\section{LITERATURE CITED}

JÜLICH W. 1984. Die Nichtblätterpilze Gallertpilze und Bauchpilze. Aphyllophorales, Heterobasidiomycetes, Gasteromycetes. Kleine Kryptogamenflora. VEB G. Fischer Verl. Jena. pp. 626.

KARASIŃSKI D. 2009. Preliminary results of studies on the genus Ramaria (Fr.) Bonorden in Poland: 49-50. In: Dynowska M., Ejdys E. (eds), Ogólnopolskie Sympozjum Mikologiczne. Interdyscyplinarny charakter mikologii. Olsztyn-Krutyń 10-12 września 2009. Wydawnictwo Uniwersytetu Warmińsko-Mazurskiego w Olsztynie, Olsztyn, pp. 132.

KIRK P.M., CANNON P.F., MINTER D.W., STALPERS J.A. 2008. Ainsworth \& Bisby's Dictionary of the Fungi. Tenth Edition. CABI Europe - UK, Wallingford, pp. 640.

ŁUSZCZYŃSKI J. 2008. Ramaria rubella (Schaeff.) R.H. Petersen - the first record in Central and Eastern Europe. Acta Soc. Bot. Pol. 77(3): 241-243.

PETERSEN J.H. 1997. Ramariaceae Corner. In: Hansen L., Knudsen H. (eds). 1997. Nordic Macromycetes, Vol. 3. Heterobasidioid, aphyllophoroid and gastromycetoid Basidiomycetes. Nordsvamp, Copenhagen. pp. 444.

PETERSEN R.H. 1975. Ramaria subgenus Lentoramaria with Emphasis on North American Taxa. Biblioth. Mycol. 43:1-161.

WOJEWODA W. 2003. Checklist of Polish larger Basidiomycetes. Krytyczna lista wielkoowocnikowych grzybów podstawkowych Polski. In: Mirek Z. (ed.), Biodiversity of Poland. Bioróżnorodność biologiczna Polski 7. W. Szafer Institute of Botany, Polish Academy of Sciences, Kraków, pp. 812. 